\title{
Impacts Of Changing Financial And International Market Conditions On Output For Colombia
}

Yu Hsing, Southeastern Louisiana University, USA

Michael C. Budden, Southeastern Louisiana University, USA

Antoinette Phillips, Southeastern Louisiana University, USA

\begin{abstract}
Potential effects of financial stock values, world market demand, exchange rate fluctuations and other factors on output variations for Colombia are examined. An open macroeconomic model is developed to include the goods market, the monetary policy, and the formulation of inflation. The sample consists of quarterly data ranging from 1994.Q1 to 2007.Q2 with a total of 54 observations. A generalized least squares (GLS) method is employed in order to correct for both heteroskedasticity and autocorrelation simultaneously. The results indicate a higher stock market value, real appreciation of the peso, higher world market demand, a lower U.S. real interest rate, and a lower expected inflation rate would increase real output for Colombia. Increased deficit spending would not help raise real output, suggesting that fiscal prudence may be needed.
\end{abstract}

Keywords: financial stock price, world market demand, exchange rate, macroeconomic policies, Colombia

\section{INTRODUCTION}<smiles>C1=CCCCC=1</smiles>

tudies examining the effects of various macroeconomic variables on particular countries' economies are becoming increasingly prevalent (e.g., Bribiesca Aquirre, 2007). The global financial crisis has affected many developing countries including Colombia (Landauro, 2008a, 2008b; Moffett, 2008). The Bogota Stock Exchange index has declined a great deal from its high. The weak world economy is expected to affect Colombia's exports. The peso has depreciated significantly against the U.S. dollar. Monetary policy has eased in an effort to stimulate the economy. This easing may cause the peso to depreciate and the inflation rate to rise. Whether expansionary or prudent fiscal policy should be pursued remains unsettled.

This effort examines the relationship between output fluctuations in Colombia and major economic variables including financial market performance, world demand, the real exchange rate, and real government deficit spending with several focuses. First, a three-equation simultaneous model is considered to determine the equilibrium real output. In the model, the specification of the monetary policy function and inflation targeting is consistent with the monetary policy that the central bank of Colombia has been pursuing. For example, the central bank of Colombia (2008) determined the inflation targeting range to be between $3.5 \%$ and $4.5 \%$ for year 2008. Second, comparative-static analysis is applied to find any potential impact of a change in the real exchange rate on the equilibrium real output. Third, a generalized least squares (GLS) method is employed to yield consistent estimates for the covariance and standard errors.

\section{LITERATURE SURVEY}

Several researchers have studied output growth, money policy, fiscal policy, exchange rate policy, and other related subjects for Colombia. Abrego and Österholm (2008) used a Bayesian vector-autoregressive (VAR) model to estimate variance decomposition and found that world output growth and government spending accounted for $17 \%$ and $16 \%$ of GDP variation for Colombia, respectively. Restrepo (2000) indicated that increased central 
bank independence in Colombia led to lower inflation and smaller inflation variability. Restrepo proferred that foreign debt to finance fiscal deficits and less independence of the central bank of Colombia may explain why inflation rates were higher than expected. Arango, Iregui, and Melo (2006) found that monetary policy conducted at the end of the 1990s was neutral to output and unemployment and that the increase in unemployment was attributable to an increase in non-wage labor costs and backward-formulated expectations of wage determination. The new monetary regime instituted in 1999 has made monetary policy less counter-cyclical and has not led to a decrease in output volatility in Colombia (de Mello and Moccero, 2007). The International Monetary Fund (IMF) (2008b) expected the central bank of Colombia to contain rising inflation, restrain strong growth of aggregate demand, and pursue a soft landing. Its measures to increase the policy interest rate by 350 base points to $9.5 \%$ and to impose an uncompensated reserve requirement on new deposits in May 2007 were viewed as moving in the right direction. The IMF recommended the central bank of Colombia select a longer time horizon of 18-24 months in inflation targeting.

Leigh (2008) demonstrated prudent fiscal policy in response to excess tax revenues could improve the trade balance, reduce exchange rate volatility, and mitigate the central bank's burden to adjust interest rates. According to the IMF (2008b), structural fiscal reforms have increased the privatization or commercialization of governmentowned enterprises in the oil-producing and electricity-generating sectors, reduced the corporate income tax rate from $38.5 \%$ in 2006 to $33 \%$ in 2008 , reduced energy subsidies, and are responsible for phasing out the $7 \%$ tax on outward remittances and the stamp tax on bank loans. To reduce an overheated economy, the authorities need to pursue a tighter fiscal policy by reducing public debt and engaging in structural reforms. The IMF further recommended the authorities consider reducing value-added tax (VAT) rates, tax exemptions and payroll tax, repeal the financial transactions tax, and reduce mandatory spending and revenue earmarking.

Rajapatirana (1999) analyzed trade issues for 6 South American countries including Colombia. He demonstrated, among other findings, that import restrictions could not solve trade deficits, that real devaluation before or during liberalization would be needed for trade liberalization to take effect, and that trade liberalization helped exports whereas trade restrictions hurt exports. Fernandes (2007) found evidence that tariff liberalization had a positive effect on plant productivity. This positive impact increased with plant size and was larger for less competitive sectors.

While Chan, Landry and Jalbert (2004) were not looking directly at Colombian firms, they discussed several effects of fluctuating exchange rates on firms' financial statements and cash flows. Feinberg (2000) revealed the incomplete pass-through of exchange rate variations into domestic prices for Colombia was due partly to entry barriers and trade openness had a limited impact on the domestic price of import-competing products. Rowland (2004) found $80 \%$ of import price change, $28 \%$ of producer price change, and $8 \%$ of consumer price change in Colombia were attributable to exchange rate variations. Hence, exchange rate pass-through was significant for import prices, modest for producer prices, and small for consumer prices. Joyce and Kamas (2003) examined exchange rate movements for Colombia, Argentina, and Mexico. Joyce and Kamas reported that without considering nominal variables, productivity and the terms of trade explained most of the variation in real exchange rates and by including nominal variables, nominal exchange rates explained most of the changes in real exchange rates. The IMF (2008b) estimated the real exchange rate was in line with macroeconomic fundamentals and that potential risk of contagion due to the global sub-prime market would be relatively small. The IMF emphasized Colombia needs to reduce the current account trade deficit and diversify heavy reliance of exports to Venezuela by pursuing free trade agreements (FTAs) with the U.S. and other countries. A review of these articles suggests that few of the previous studies have applied a general equilibrium model of the financial sector, world demand, the foreign exchange rate and other related variables to examine aggregate economic output.

\section{THE MODEL}

Applying and extending Romer (2000, 2006), the open macroeconomic model for Colombia may be expressed as:

$$
Y=V(Y, R, G, T, \varepsilon, S, W Y)
$$




$$
\begin{aligned}
& R=X\left(\pi, Y, \varepsilon, R^{*}\right) \\
& \pi=\pi^{e}+\theta\left(Y-Y^{*}\right)+\phi \varepsilon
\end{aligned}
$$

where

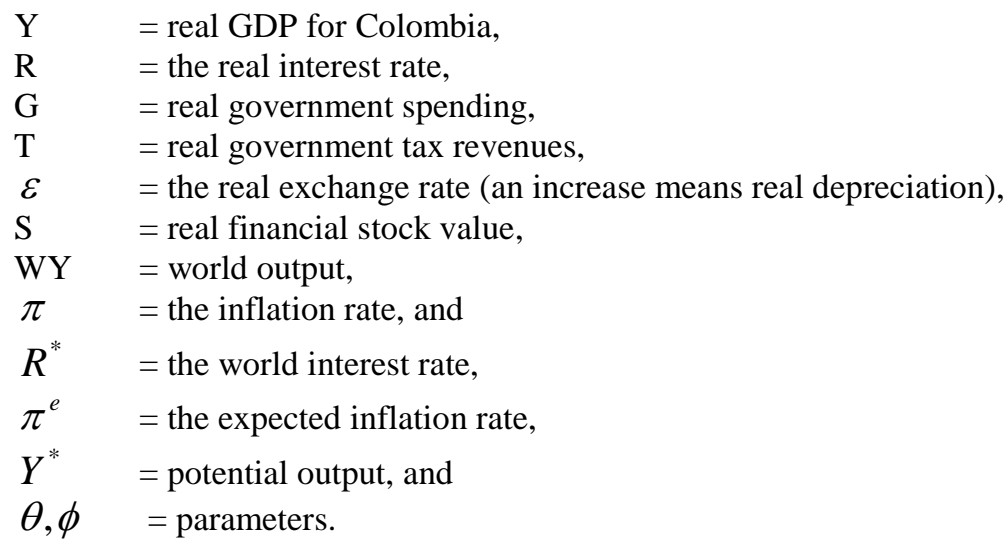

Solving for three unknowns $Y, R$ and $\pi$, the equilibrium real GDP can be expressed as a function of the exogenous variables and parameters:

$$
\begin{gathered}
\bar{Y}=\bar{Y}\left(S, W Y, \varepsilon, R^{*}, G, T, \pi^{e} ; \phi, \theta, Y^{*}\right) \\
++ \pm-+-
\end{gathered}
$$

The sign below each of the variables indicates the expected relationship with real GDP. The partial derivative of the equilibrium real GDP with respect to the real exchange rate is given by:

$$
\partial \bar{Y} / \partial \varepsilon=\left(V_{\varepsilon}+\phi V_{R} X_{\pi}+V_{R} X_{\varepsilon}\right) /|J|>\text { or }<0
$$

where $|J|$ is the Jacobian of the three simultaneous equations with a positive value. As shown, the sign of $\partial \bar{Y} / \partial \varepsilon$ is unclear because of the expected positive impact on net exports and the expected negative impacts on real GDP due to a higher inflation rate and a higher real interest rate.

Although government deficit spending theoretically would raise output, there are several reasons that government deficit spending may not be effective in the long run. The Ricardian equivalence hypothesis (Barro, 1989) indicates that deficit-financed government spending may have a neutral effect in the long run because people would expect the government would raise taxes in the future to pay for the debt incurred in the current period. Taylor (2000) demonstrated the effect of government deficit spending was uncertain and unclear due to impact lags, crowding-out, increases in interest rates, irreversible constraints, and related factors.

\section{EMPIRICAL RESULTS}

The data used in this analysis can be found in International Financial Statistics (2008a), published by the International Monetary Fund, Washington, DC. Real GDP, real government deficit spending are expressed in billion pesos. To reduce a high degree of multicollinearity among right-hand side variables, real government deficit, which is defined as $\mathrm{G}-\mathrm{T}$, is chosen for the empirical test. The real stock price is the share price index adjusted for the consumer price index (CPI). Industrial production in advanced countries is selected to represent world output or demand. The real exchange rate is equal to the nominal peso/USD exchange rate times the relative price in the U.S. 
and Colombia. The U.S. real federal funds rate is chosen to represent the world real interest rate. The inflation rate is derived from the percent change in the CPI. The expected inflation rate is the average inflation rate of the past four quarters. Except for variables with negative values, the log scale is used so that the estimated coefficient is the elasticity. The sample data ranges from 1994.Q1 to 2007.Q2 with a total of 54 observations. Estimated parameters and related statistics are presented in Table 1.

The Newey-West (1987) method is employed because it yields consistent estimates of the covariance and standard errors for valid hypothesis tests. As shown, the right-hand side variables can explain $94.4 \%$ of the variation in the equilibrium real GDP. Except for the coefficient of real government deficit, the coefficients of the real stock price, world output, the real exchange rate, and the expected inflation rate are significant at the .01 level, and the coefficient of the real federal funds rate is significant at the .10 level. Real GDP has a positive relationship with the real stock price and world output and a negative relationship with real depreciation, the real federal funds rate, and the expected inflation rate.

Table 1: Estimated Regression of $\log ($ Real GDP) for Colombia: 1994.Q1 - 2007.Q2

\begin{tabular}{|c|c|c|}
\hline Variable & Coefficient & t-Statistic \\
\hline Log(real stock price) & 0.065 & 6.589 \\
\hline $\log ($ world output) & 0.495 & -2.336 \\
\hline $\log ($ real exchange rate) & -0.162 & -1.803 \\
\hline $\log ($ real federal funds rate) & -0.006 & -0.635 \\
\hline Real government deficit & $-1.14 \mathrm{E}-06$ & -3.233 \\
\hline Expected inflation rate & -0.029 & 10.811 \\
\hline Intercept & 8.605 & \\
\hline Adjusted R-squared & 0.944 & \\
\hline Akaike information criteria (AIC) & -4.536 & \\
\hline Schwarz criteria (SC) & -4.279 & \\
\hline F-statistic & 148.776 & \\
\hline
\end{tabular}

Several observations can be made from the results. Higher real stock values would stimulate the economy mainly through the wealth effect of more household spending and the balance-sheet effect of more business investment spending (Kuttner and Mosser, 2002). The weak global economy is expected to have a negative impact on real output for Colombia. The conventional approach to devalue a currency to boost exports may not apply since real depreciation of the peso would reduce real output. Monetary tightening by the U.S. Federal Reserve Bank would hurt Colombia's real output. When the expected future price rises, it would reduce aggregate supply and real GDP.

Several different formulations of the model were considered and estimated. When the ratio of deficit spending to GDP substitutes for real government deficit, the coefficient is still negative and insignificant at the $10 \%$ level. When a linear form is employed, the value of $\mathrm{R}^{2}$ is 0.940 . Other results are similar. The mean absolute percent error (MAPE) of 1.995 for the linear form is greater than the MAPE of 1.829 for the log form reported in Table 1.

\section{SUMMARY AND CONCLUSIONS}

This study examined output fluctuations for Colombia based on an open macroeconomic model. The equilibrium in the goods market and the money policy function are considered simultaneously. Comparative-static analysis is presented to evaluate the impact of a change in the real exchange rate on the equilibrium real output. The Newey-West model is employed to provide valid hypothesis tests. A higher real stock value, more world output, real appreciation of the peso, a lower world real interest rate, and a lower expected inflation rate would increase real GDP whereas increased government deficit spending would fail to raise real GDP. Hence, fiscal discipline is needed in order to maintain efficient government service and allow the private sector to play a major role in economic growth. 
There may be areas for future research. Country risk may be considered based on political, economic, and financial factors. The expected inflation rate may be constructed by more sophisticated methods. The model may be specified differently to replace the monetary policy function with a money demand function.

\section{AUTHOR INFORMATION}

Yu Hsing, Ph.D., Professor of Economics, Department of Business Administration, College of Business

Michael C Budden, Ph.D., Mayfield Professor of Marketing, Department of Marketing \& Finance, College of Business

Antoinette Phillips, Ph.D., Professor of Management, Interim Head of the Department of Business Administration, College of Business

\section{REFERENCES}

1. Abrego, L. and P. Österholm 2008. "External Linkages and Economic Growth in Colombia: Insights from A Bayesian VAR Model," Working Paper No. 08/46, February 1.

2. Arango, L. E., A. M. Iregui, and L. F. Melo 2006. "Recent Macroeconomic Performance in Colombia: What Went Wrong?" Revista de Economia del Rosario, 9(1): 1-19.

3. Barro, R. J. 1989. "The Ricardian Approach to Budget Deficits," Journal of Economic Perspectives, 3(2): $37-54$.

4. Bribiesca Aquirre, J. C. 2007. "Risk Management: Impact of the Macroeconomic Variables in the Stock Market Sectors," International Business and Economics Research Journal, 6(7): 59-66.

5. Central Bank of Colombia, 2008. "How is Monetary Policy Implemented in Colombia," http://www.banrep.gov.co/monetary_policy/index.html.

6. Chan, C, Landry, S. P. and T. Jalbert, 2004. "Effects of Exchange Rates on International Transfer Pricing Decisions," International Business and Economics Research Journal, 3(3): 35-48.

7. de Mello, L. and D. Moccero 2007. "Monetary Policy and Macroeconomic Stability in Latin America: The Cases of Brazil, Chile, Colombia and Mexico," OECD Economics Department, OECD Economics Department Working Papers: 545.

8. Feinberg, R. M. 2000. "The Role of International Discipline in Three Developing Economies: Exchange Rate Effects on Domestic Prices in Colombia, Korea, and Morocco," Review of International Economics, 8(1): 26-133.

9. $\quad$ Fernandes, A. M. 2007. "Trade Policy, Trade Volumes and Plant-Level Productivity in Colombian Manufacturing Industries," Journal of International Economics, 71(1): 52-71.

10. International Monetary Fund, 2008a. International Financial Statistics. Washington, DC. http://www.imfstatistics.org/imf/.

11. International Monetary Fund, 2008b. "Colombia: 2005 Article IV Consultation and Fourth Review Under the Stand-By Arrangement, Requests for Waiver of Nonobservance of Performance Criteria and the Completion of the Fourth Review, and Request for Stand-By Arrangement--Staff Reports; Public Information Notice and Press Release on the Executive Board Discussion; and Statement by the Executive Director for Colombia," May 9.

12. Joyce, J. P. and L. Kamas 2003. "Real and Nominal Determinants of Real Exchange Rates in Latin America: Short-Run Dynamics and Long-Run Equilibrium," Journal of Development Studies, 39(6): 155182.

13. Kuttner, K. N. and P. C. Mosser 2002. "The Monetary Transmission Mechanism: Some Answers and Further Questions," Federal Reserve Bank of New York Economic Policy Review, 8(1): 15-26.

14. Landauro, I. 2008a. "Colombia Aug Industrial Output Contracts $8.8 \%$ On Yr -DANE," Dow Jones Newswires, Bogota, October 22.

15. Landauro, I. 2008b. “Colombia Sep Urban Jobless Rate 11.3\% Vs 10.5\% Yr Ago," Dow Jones Newswires, Bogota, October 31.

16. Leigh, D. 2008. “Achieving a Soft Landing: The Role of Fiscal Policy,” International Monetary Fund, IMF Working Papers: 08/69. 
17. Moffett, M. 2008. "Colombia Wants the World to Recognize Its Passion; Latin American Nation Trots Out a New Slogan, Seeking to Rehabilitate Its Brand After Years of Violence and Corruption," Wall Street Journal, (Eastern edition), October 27, B.4.

18. Newey, W. K. and K. D. West 1987. "A Simple, Positive Semi-definite, Heteroskedasticity and Autocorrelation Consistent Covariance Matrix," Econometrica, 55(3): 703-708.

19. Rajapatirana, S. 1999. "Trade Policies, Macroeconomic Adjustment, and Manufactured Exports: The Latin American Experience,” The World Bank, Policy Research Working Paper Series: 1492.

20. Restrepo, J. M. 2000. "Central Bank Independence and Inflation: The Case of Colombia, 1924-1998," Revista de Economia del Rosario, 3(1): 37-63.

21. Romer, D. 2000. "Keynesian Macroeconomics without the LM Curve," Journal of Economic Perspectives, 14(2): $149-169$.

22. Romer, D. 2006. Advanced Macroeconomics, third edition. New York, NY: McGraw Hill.

23. Rowland, P. 2004. "Exchange Rate Pass-Through to Domestic Prices: The Case of Colombia," Ensayos sobre Politica Economica, 47: 106-125.

24. Taylor, J. B. 2000. "Reassessing Discretionary Fiscal Policy," Journal of Economic Perspectives, 14(3): 21-36.

\section{$\underline{\text { NOTES }}$}

